\title{
An integrated approach to water protection and management: the European Union model
}

\begin{abstract}
Purpose - The paper examines the European Union Water Framework Directive. It seeks, firstly to determine whether its provisions align with modern thinking on integrated river basin management, and secondly to assess the degree to which it has the potential to achieve legislative and inter-agency integration throughout the Union.
\end{abstract}

Design/methodology/approach - This was a desk top study. The paper draws upon theories and definitions of integrated river basin management and internal integration in existing literature and then proceeds to examine the provisions of the Water Framework Directive in the light of the models identified.

Findings - The framework for river basin management in the Water Framework Directive does not fully match the modern approach to integrated river basin management. The Directive is limited by its primary focus upon the single medium of water, and its consequent failure to fully address wider land use planning issues. It therefore also fails to achieve integration between all relevant legislative instruments. It provides a framework for stakeholder involvement that could potentially serve the goal of inter-agency integration. However, due to the high level of discretion in the hands of member states, there is likely to be a substantial divergence of practice across the European Union.

Originality/value - In assessing the Water Framework Directive against modern notions of river basin management and the Directive's stated integrative aspirations, the paper informs implementation and practice in member states.

Keywords - Regulation, Environment, Water, Integration, River Basin Management

Paper type - Research paper 


\section{Introduction}

The importance of an integrated approach to all aspects of the regulation of the built and natural environments is increasingly being recognised. The environment comprises multiple media, each of which interacts with each other. The environmental media must also be viewed within the overall context of the aim of sustainable development and social, economic and political pressures. In the area of water protection and management, new approaches have recently been adopted that look at a more integrative approach. In particular, the Water Framework Directive ${ }^{1}$ represents a revolutionary shift in the way the European Union addresses water legislation (Le Quesne \& Green, 2005). It has been predicted that it will dramatically change the future topography of EU water law (Howarth and McGillivray, 2001) and have key significance in terms of integrated planning in the entire river basin unit (Institute for European Environmental Policy, 1999). This paper considers two aspects of the Directive's possibilities to act as an integrative force. Firstly, it examines the provisions for river basin management in the Directive, in the light of modern definitions of 'integrated river basin management' and secondly, the paper aims to identify features within the Directive that contribute to effective inter-instrumental integration and inter-agency integration; both of which have been identified as key elements in achieving an overall aim of internal integration, which, it is argued, is crucial for effective environmental protection (Faure, 2000).

\section{Background}

The river basin concept is by no means a new one. Management of water resources within a river basin framework can be traced back thousands of years to the fluvial civilisations of the Nile and Tigris-Euphrates (Teclaff, 1996). The river basin unit provides a natural division for the consideration of water use and protection and planning in catchment areas has been a feature of legislative measures over a long period of time. One of the earliest pioneering river basin enterprises, and one that

\footnotetext{
${ }^{1}$ Directive 2000/60/EC establishing a framework for Community action in the Field of Water policy [2000] OJ L327/1 (WFD).
} 
provided the prototype for others worldwide, was the Tennessee Valley Authority in the United States (Teclaff, 1996). This unique body took the form of a government corporation with wide-ranging powers of planning, development and operation of all kinds of projects and had, amongst its aims, the achievement of economic and social development goals (Teclaff, 1967). The early ventures into river basin management featured highly autonomous corporate bodies with separate funding, responsible to central government and, although they led to a general acceptance of the river basin entity, they did not allow for the integration of stakeholders (Burchi et al, 1985). Valley authorities of more limited scope, dealing with just water supply and pollution abatement were established subsequently throughout Europe (Burchi et al, 1985). Characteristic of the European model is a composition of both local authority representatives and private enterprise and a two tier structure co-ordinated at national level but decentralised at regional/basin level (United Nations, 1975). The river basin concept is not alien in the United Kingdom, where administrative units have long been based upon river basins and the ten regional water authorities created in 1973 were similar in nature to those in existence elsewhere in Europe.

Since the early days of regulating activities in river basin units, when management was purely for exploitation and usually single-use orientated, the notion of management of the river basin and its ambit and aims have changed significantly. As advances were made in engineering and technology and reliable data became available for stream and eco-system modelling, the management of water resources took on a more comprehensive character. An awareness of the interrelationships between ecological, socio-economic and political priorities and an increased ability to balance these competing interests brought still further elements into the management of the basin (Wengert, 1985). Over a period of time, management of the river basin unit came to adopt an eco-system approach. Following the Stockholm Conference of $1972^{2}$ its scope was extended to include groundwater, and both the 1992 Dublin Conference on Water

\footnotetext{
${ }^{2}$ United Nations Conference on the Human Environment, 1972
} 
and the Environment ${ }^{3}$ and the 1992 Rio Conference ${ }^{4}$ called for comprehensive management of resources using the river basin as a focus. This theme was echoed at the World Summit on Sustainable Development at Johannesburg in $2002^{5}$. River basin management entities generally now aim for 'integrated river basin management', although the terminology used is varied and somewhat confusing. Some commentators prefer to use the terms 'comprehensive' or 'holistic' management (Barrow, 1998) and others draw distinctions between the different terms (Mitchell, 1990).

For the purposes of assessing the plans for river basin management within the Water Framework Directive, 'integrated river basin management' will be taken to include the five basic components identified by Downs et al (1991); namely: water, channel, land, ecology and human activity. In addition, integrated river basin management should require consideration of all dimensions of water (surface water, groundwater, quality and quantity), the interaction between the water system and other systems (e.g. land and air) and its interaction with social and economic development (Mitchell, 1990). This not only reflects an eco-systemic approach but also recognises the relationship between land use and water resources. The idea of integrated river basin management, as it has developed and expanded in scope, has become increasingly complex, with a requirement to consider and to balance a multitude of often competing factors. It has been suggested that the river basin has now gone beyond its relevance as a geographical unit for water resources development and management purposes and become a political and ideological construct (Molle (2009). In practical terms there are suggestions that the difficult and unwieldy task involved has led to disappointing results in effective management (Huffman, 2008, Barrow, 1998) and that a less comprehensive approach is necessary to gain practical success (Mitchell,1990).

\footnotetext{
${ }^{3}$ Dublin Statement, 1992

${ }^{4}$ Agenda 21 United Nations Conference on Environment and Development, 1992

${ }^{5}$ Report of the World Summit on Sustainable Development, Johannesburg, 26 August - 4 September, 2002 UN Doc.A/CONF. 199
} 


\section{The Water Framework Directive}

It is not the purpose of this paper to provide an exhaustive account of all the provisions for river basin management contained in the Directive. The central aim of the Directive is to achieve 'good water quality' and the main mechanism for reaching this goal is the ‘river basin management plan’. In summary, the Water Framework Directive requires Member States to identify river basins and assign these to river basin districts. A competent authority with responsibility for river basin districts is also to be identified. River basin management plans are then to be produced, for which some technical specifications are provided in annex VII of the Directive. The plans are to include an initial analysis of the characteristics of the river basin, a review of human activity impact on surface and groundwater and an economic analysis of water use as required by article 5 . Special protection areas are to be identified for drinking water, habitat protection and bathing water and monitoring programmes are to be put in place to provide an overview of water status. Details of the programme of measures required in article 11 to achieve the environmental objectives for good water quality status are also to be included in the plan. In essence, the plans are to provide an evaluation of existing legislation, highlighting any deficiencies and thereby indicating the measures required to address these shortcomings. They also allow for an evaluation of the cost-effectiveness of improvement measures, provide information and allow for public participation both before and after the plan production stage.

The programme of measures that is to be drawn up for each river basin district will clearly be of significant importance. While seeking to attain the environmental objectives of the Directive, the programme will also take into account the analysis of the river basin district characteristics, the review of human activity and analysis of water use. However, there is no clear indication exactly what the measures contained in the programme should be. There is an obligation to include 'basic measures', for which a fairly comprehensive list is provided; these are clearly designed to meet the specific legislative objectives of the Water Framework Directive and other existing EU water law. 'Supplementary measures' are also to be adopted in cases where the 'basic measures' are inadequate to achieve the 'good water status' objective. Part B of annex 
VII to the directive gives a non-exclusive list of 'supplementary measures' with a final category of 'other relevant measures'.

\section{Integrated river basin management}

The outline for river basin management provided in the body of the Water Framework Directive does not explicitly embrace an integrated approach. However, the need for such an approach is acknowledged in the preamble of the Directive. Preamble 18 calls for co-ordination and integration of the overall principles and structures for protection and sustainable use of water and Preamble 34, for the integration of qualitative and quantitative aspects of surface water and groundwater. Also the 'Common Strategy on the Implementation of the Water Framework Directive ${ }^{6}$ sets out a clearly defined integrative role for the river basin management plans. How then do the provisions of the Directive contribute to the development by member states of systems for river basin management that will align with the modern, integrated approach?

There is no doubt that the river basin management scheme outlined in the Directive is, in many respects, limited. In the first instance, it is restricted to water only and there is no consideration of the water system interacting with other systems. The key omission here is of any acknowledgement of the inter-relationship between water use and land use planning. The only concession to land use considerations within the Directive itself is a requirement to include, in the programme of measures, any measures required by the Environmental Impact Assessment Directive. The necessity to consider land use issues is, however, clearly identified in the guidance documents and it is also recognised by the Environment Agency in the United Kingdom in their call for 'a clear and statutory interface between land-use planning and river basin plans', which they see as 'critical for the successful implementation of the Directive' (Environment Agency, 2003). Specific inclusion of land use in the Water Framework Directive was unlikely given the

\footnotetext{
${ }^{6}$ Common Strategy on the Implementation of the Water Framework Directive, Guidance on Public Participation in Relation to the Water Framework Directive, December 2002 p13; Best Practices in River Basin Planning, Work Package 2 Guidance on the Planning Process, Version 4.3, May 2003 p10.
} 
firm position traditionally adopted by individual Member States on retaining state control of planning issues. This is reflected in the requirement for unanimity for land use planning measures in article 175(2) of the Treaty and the strong reliance on the subsidiarity $^{7}$ requirement in this area. In terms of considering the interaction between the water system and other systems, therefore, the provisions of the Directive do not contribute greatly to this feature of integration in river basin management and it is left in the hands of the individual Member States to legislate in order to tie land use into river basin management and to follow the non-binding EU level guidance in this respect.

Turning to the two other manners of contemplating integrated river basin management outlined by Mitchell (1990); the Directive does, to some degree, succeed in considering all dimensions of water; both surface water and groundwater fall within its remit, as well as transitional and coastal waters. Also, in terms of good groundwater quality, as required by article 4(1)(b)(ii) of the Water Framework Directive, status is to be determined by the poorer of its quantitative and chemical status and, as previously indicated, there is clear direction in the Directive's preamble to consider qualitative and quantitative aspects of both groundwater and surface water. It can be argued that the interaction between the water system and social and economic development is also recognised within the Directive itself. There is a requirement for the review of human activity impact and an economic analysis of water use, as well as recognition of the role of economic factors in attaining the goal of good water quality. However, the economic analysis is restricted to the carrying out of calculations to enable recovery of the costs of water services under article 9 and the impact review, although its requirements are fairly wide-ranging, looks only at the anthropogenic pressures on surface and groundwater and does not consider the social benefit or disbenefit of water protection and management. Also, a true view of the interaction between water and social/economic development would require land use planning issues to be incorporated.

\footnotetext{
${ }^{7}$ EC Treaty art 5 (2).
} 
Clearly then, the framework for river basin management set out in the Water Framework Directive does embrace some of the features of the modern day concept of integrated river basin management. However, there are some glaring omissions, most notably a specific requirement to consider the interaction with other media, in particular with the land. Also, importantly, there is no elaboration within the instrument on how the river basin plans and programmes of measures are to serve the integrative aim. It should, however, be remembered that more comprehensive systems of integrated river basin management have been criticised for their complexity and lack of practical workability. It has been suggested that, at operational level, although an integrated approach is necessary, attention should be directed to a smaller number of variables that account for a large proportion of the problem (Mitchell, 1990). Nonetheless, land use planning should not be regarded as an expendable consideration when selecting the variables to be taken into account in river basin planning and management.

\section{Internal Integration}

The remaining section of this paper assesses the Water Framework Directive's potential contribution to the general goal of 'internal integration'. This aim should be distinguished from that of 'external integration', which is the most common usage of the term integration in EC law and refers to the integration of environmental considerations into other sectoral policies and activities. Faure (2000) defines 'internal integration' as cross-media integration in decision-making and contends that this is crucial for effective environmental protection. He identifies two key aspects of internal integration: crossagency integration (both vertical and horizontal) and instrumental integration. These are generally recognised as key elements in achieving an overall aim of internal integration (Anker, 2002). As identified above, although the river basin management regime in the Directive does not fully match the modern approach to integrated river basin management, it undoubtedly has features that will contribute to cross-media integration. The questions of inter-instrumental and inter-agency integration will now be considered 


\section{Inter-instrumental integration}

In order to gauge the Directive's role in inter-instrumental integration, it is necessary to first consider previous approaches to water quality law by the European Union. Traditionally the EU approach was a sectoral one and legislation tended to be based on one or more of three control techniques: Where substances were considered inherently dangerous, an emissions control approach was adopted. Otherwise, quality objectives were employed and waters classified by end use (e.g. shellfish waters and bathing waters). With this second category of instruments the emphasis was on the impact of pollutants on a specified quality standard. A third group of measures sought to regulate the activities that can result in water pollution (e.g. treatment of sewage). The first phase of early EU water legislation introduced quality objectives for drinking water, freshwater fish waters, shellfish waters, bathing waters and ground waters. The Dangerous Substances Directive ${ }^{8}$, on the other hand, primarily adopted an emission control approach but with a parallel alternative option for member states to work with limit values for quality. By 1988, it was recognised by the European Commission that there were gaps to be filled. The second phase of water legislation, therefore, addressed sewage and agricultural sources through the Urban Waste Water Treatment Directive ${ }^{9}$ and the Nitrates Directive ${ }^{10}$. Drinking water quality objectives were further tightened in a revised Drinking Water Directive of $1998^{11}$. The only measure, however, that reflected an integrated approach and consideration of cross-media impacts came in the

\footnotetext{
${ }^{8}$ Directive 76/464/EEC on pollution caused by certain dangerous substances [1976] OJ L129/23.

${ }^{9}$ Directive 91/271/EEC concerning urban waste-water treatment [1991] OJ L135/40.

${ }^{10}$ Directive 91/676/EEC concerning the protection of waters against pollution caused by nitrates from agricultural sources [1991] OJ L375/1.

${ }^{11}$ Directive 98/83/EC on the quality of water intended for human consumption [1998] OJ L257/26.
} 
form of the 1996 Integrated Pollution Prevention and Control Directive ${ }^{12}$, which looked at the impact of pollutants on all three environmental media.

The need for a more comprehensive approach to water legislation, was identified by the Council of Ministers, in 1988 and the Council then exerted pressure on the Commission who finally accepted a request to develop a new EU water policy made by the European Parliament and the Environment Committee in consultation with the Council of Environment Ministers in mid 1995. A dichotomy was recognised in the approach to EU pollution control between control at source and receiving environment quality objectives. Both approaches revealed problems; source control, on the one hand, can result in cumulative pollution load from multiple sources, whereas quality standards, on the other hand, rely on scientific knowledge as to the effect of the pollutants on the ecosystem. The Commission acknowledged that a combined approach was needed ${ }^{13}$. The Water Framework Directive was the instrument designed to achieve this and to draw together and build on existing legislation in order to attain greater legislative coherence and to gain greater integration in the practical implementation of the law. In this instrument the legislators specifically aimed to achieve integration between; water quantity and water quality issues, surface water management and groundwater management, water use and environmental protection, control of pollution through emission controls and through quality objectives and between water policy and other policies ${ }^{14}$.

There is a clear aim and role for the Water Framework Directive in contributing to interinstrumental integration. The Directive, as its name suggests, sets a framework for attaining good water quality in all nature of water bodies and, therefore, consolidates by

\footnotetext{
12 Directive 96/61/EC concerning integrated pollution prevention and control [1996] OJ L257/26.

13 Communication from the Commission to the Council and the European Parliament, European Community Water Policy, COM (96) 59 final.

${ }^{14}$ Ibid., s8.
} 
repealing a number of existing measures dealing with specific water environments ${ }^{15}$. A good many legislative instruments are kept in place, although these are firmly tied to the Water Framework Directive ${ }^{16}$. The requirement to identify and make provisions for the protection of drinking water and protected areas is illustrative of the inter-instrumental integrative capacity of the Directive. Areas for conservation of habitats and species are also to be identified and dealt with under river basin management plans ${ }^{17}$ and, likewise, member states are directed to ensure that waters used for the abstraction of drinking water meet the requirements of the drinking water directives ${ }^{18}$. It is interesting to note, however, that proposals to link more closely the new bathing water directive ${ }^{19}$ to the Water Framework Directive were rejected. The overall approach taken in the Water Framework Directive, in order to tackle point and diffuse source pollution, is one of attaining the stricter standard between the legislative instruments that remain and the Framework Directive ${ }^{20}$, thereby assuring a good level of integration between different pieces of water legislation. The Directive also takes a dual approach to protection of the water environment, requiring whichever is the stricter of emission standards or quality objectives must be met ${ }^{21}$.

As previously noted, there is little in the Directive to link the regulation of the water system with that of other media and it is this feature of inter-instrumental integration that is crucial to the overall goal of internal integration. Apart from the consideration

\footnotetext{
${ }^{15}$ WFD, Art 22 (including the Freshwater Fish, Shellfish Water and Groundwater Directives).

${ }^{16}$ The key measures in this category being; the first Detergent Directive, the Bathing Water Directive, the Drinking Water quality Directives, the Urban Waste-water Treatment Directive and the Nitrates Directive.

${ }^{17}$ WFD, Art 6.

${ }^{18}$ Directives 80/778 and 98/83.

${ }^{19}$ Directive 2006/7/EC concerning the management of bathing water quality OJ L64/37

${ }^{20}$ WFD, Art 10.

${ }^{21}$ WFD, Art 10 (3).
} 
given to the IPPC Directive, there is no requirement to refer to legislation in the spheres of air and land and, despite the Commission's commitment in the Sixth Environmental Action Plan ${ }^{22}$ to the 'greening of land use planning and management decisions', there is little to tie the Water Framework Directive with instruments governing environmental impact assessment and strategic impact assessment ${ }^{23}$. The guidance documents, however, are not silent on these issues and advocate instrumental integration across the boundaries of the media. Whether this guidance is heeded or not will of course be a decision entirely in the hands of the individual Member States and one that will no doubt be informed by local pressures, policies and politics.

\section{Inter-agency integration}

Inter-agency integration in both directions is fundamentally dependent on the inclusion and participation of relevant stakeholders. The provisions for public information and consultation contained in article 14 of the Water Framework Directive will, therefore, be of key significance in attaining successful integration in this regard. Essentially there are three forms of public participation contained within the Directive each entailing a different degree of stakeholder involvement; information supply, consultation and active involvement. The first two of these are to be ensured and the latter encouraged. Annex VII - which dictates the content of river basin management plans - requires a summary of the public information and consultation measures taken, together with the results and any consequential changes to the plan and article 14 requires publication and availability for public comment of; timetable, work programme, statement of consultation measures, interim overview and draft copies of the plan. Background documents are also to be available on request and six months is to be allowed for comment. In terms of actual

\footnotetext{
${ }^{22}$ Decision 1600/2002/EC laying down the Sixth Community Environment Action Programme [2002] OJ L242/1.

${ }^{23}$ Directive 85/337/EEC on the assessment of the effects of certain public and private projects on the environment [1985] OJ L175/40 and Directive 2001/42/EC on the assessment of the effects of certain plans and programmes on the environment [2001] OJ L197/30.
} 
stakeholder participation in the planning process, the Directive encourages the active involvement of interested parties.

To what degree then will this stimulate inter-agency integration in the two necessary directions? In terms of vertical inter-agency integration, this can potentially be achieved by the means of active involvement of stakeholders on a multi-level basis (e.g. representatives of national, regional and local authorities) and likewise horizontal integration can be achieved by engaging stakeholders and the public in active involvement, but, as noted above, there is no absolute requirement for such a level of involvement in the Directive. The only obligations are for consultation and the provision of information, neither of which will be certain to foster inter-agency integration. Admittedly, it is difficult to legislate for the compulsory participation of stakeholders and how member states approach the issue of encouraging active participation will be crucial in attaining the necessary inter-agency integration.

In summary, the scope of the Directive, in terms of contributing to internal integration, is limited by its focus almost exclusively on one medium. Arguably, the Directive does have the potential to deliver on the European Commission's integrative aims in terms of bringing in all elements of water and consolidating existing legislation under a new and comprehensive piece of legislation, but it fails to succeed in inter-instrumental integration by virtue of failing to recognise the inter-relationship between water, air and, in particular, land use. The Directive does address the issue of stakeholder involvement. However, as is the case with so much of this framework measure, the comprehensive guidance on best practice in this respect is to be found in a non-binding guide to implementation. Reservations expressed by the UK Environment Agency suggest that the level of active involvement of stakeholders on either a horizontal or a vertical plane is likely to be limited.

\section{Conclusions}

The system of river basin management in the body of the Water Framework Directive does not explicitly adopt integration, but there are clear indications from both the Directive itself and the implementation guidance that an integrated system of 
management is envisaged. However, the task of introducing modern practices of integrated river basin management is mostly left in the hands of individual Member States, as is the option of incorporating land use issues in the planning process. It may, of course, be that there are valid practical considerations in operation here. Experience in existing river basin authorities has indicated that problems are likely to be encountered when too comprehensive an approach to river basin management is adopted at an operational level (Mitchell, 1990). Not least of the problems is the time element involved and, given the timetable imposed by the Directive for production of the first river basin management plans, a fully holistic approach was probably unrealistic. Almost certainly, political concerns have been influential in the steer away from explicit mention of land use planning in the framework for river basin management provided in the Directive. It is to be hoped that some kind of statutory provisions are adopted to allow for this in member states and, of course, given the long, staged, implementation period, time still remains to introduce more detailed requirements in future legislation. Although there is comprehensive guidance in place at EU level on integrated river basin management, it is inevitable that the systems ultimately adopted by individual member states will vary considerably depending on the local environment and pressures.

It may be that the systems of river basin management that evolve in EU member states do ensure that all environmental media are considered in decision-making and planning and also achieve the internal integration that is crucial (along with external integration) for the protection and sustainable use of our water environment. However, to do so there must be integration between legislation in place in all the environmental media. Once again, measures to ensure such integration will fall to be adopted at a national level, albeit with some guidance from the European Union. The Water Framework Directive provides a skeletal outline of possibilities for stakeholder involvement that could serve the remaining key aspect of internal integration (inter-agency integration). Yet, once more, it is left to Member States to put flesh on the bones and it is already evident that practical difficulties and time constraints are limiting the degree of active involvement by agencies, authorities and the public. Without such involvement and the opportunity to draw in all interested stakeholders, it is unlikely that the goal of interagency integration will be achieved. It is almost certainly the case that across the 
European Union practice will diverge considerably (Adshead, 2006) as will the degree of internal integration achieved. The Water Framework Directive provides the potential, implementation guidelines fill in some of the gaps, but it is in the hands of Member States to decide how best to serve the protection and management of their water resources for the future.

\section{References}

Adshead, J. (2006), "Public Participation, the Aarhus Convention and the Water Framework Directive”, Water Law, 17, p 190.

Anker, H.T. (2002), “Integrated Resource Management - Lessons for Europe?”, EELR, p199.

Barrow, C.J. (1998), "River Basin Development Planning and Management: A Critical Review”, World Development, 26, p173.

Burchi, S. (1985), "Different Types of River Basin Entities: A Global Outlook” Ludqvist, J. Lohn, U. and Falkenmark, M. Strategies for River Basin Management, 4.1.

Downs, P.W., Gregory, K.J. \& Brookes, A. (1991), "How Integrated is River Basin Management?”, Env. Management, 15, p 299.

Environment Agency Briefing Note (2003), “The Land-use Planning System and the Water Framework Directive”, version 1.

Faure, M. (2000), “Defining Harmonization, Codification and Integration”, EELR, p 174.

Howarth, W. \& McGillivray D. (2001) Water Pollution and Water Quality Law, Shaw and Sons, Kent, p 333. 
Huffman, J.L. (2008) “Comprehensive River Basin Management: The Limits of Collaborative, Stakeholder-Based, Water Governance”, unpublished, available from http://worksbepress.com/james_huffman/5/ (28.6.2009).

Institute for European Environmental Policy "The Influence of EU Policies on the Evolution of Coastal Zones”, London, 12 November 1999, Study Contract ERDF No 98.00.27.049, p 3.

Le Quesne, T. \& Green, C. (2005) “Can we Afford not to? The Costs and Benefits of a Partnership Approach to the Water Framework Directive” WWF, p 4.

Mitchell, B. (1990), “International Experience and Perspectives” Mitchell Integrated Water Management, Belhaven, p16.

Molle, F. (2009) "River-basin Planning and Management: The Social Life of a Concept”, Geoforum, 40, 3, p 484.

Teclaff, L.A. (1967), The River Basin in History and Law, Martinus Nijhoff, The Hague p 127.

Teclaff, L.A. (1996), "Evolution of the River Basin Concept in National and International Water Law”, Natural Resources Journal, 36, p361.

United Nations (1975), "Proceedings of the Interregional Seminar on Water Resources Administration”, ND1973. UN Doc EDP/UNT/INT 70.

Wengert, N. (1985), “The River Basin Concept as seen from a Management Perspective in the USA” Ludqvist, J., Lohm, U. and Falkenmark, M., Strategies for River Basin Mangement, p 299. 
